\title{
Editorial
}

\section{Conservation Crossroads: Extinction or Recovery? The U.S.A.'s Endangered Species Act at Forty}

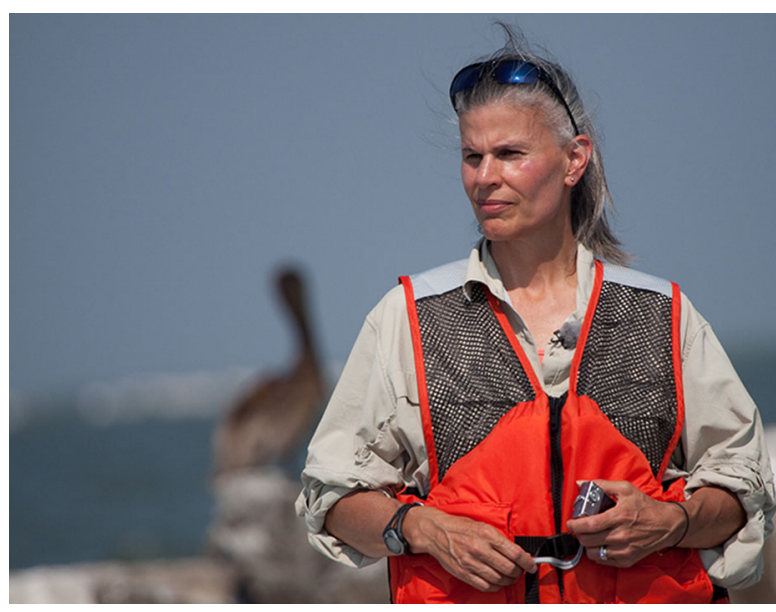

Forty years ago the picture was stark across the United States of America: factories, incinerators, and vehicles were pumping pollutants into the air, leaving a brown haze over cities all across the country and causing multiple health issues including asthma, heart disease, and lung cancer. Our waters were equally polluted with toxic chemicals, sewage, trash, and disease-carrying organisms. The Cuyahoga River in Ohio was so polluted it caught fire in 1969. And many species of wildlife were in trouble, from bald eagles and pelicans to grizzly bears and wolves. Rachel Carson was sounding the alarm, through her book Silent Spring, that pesticides such as DDT were killing many of our birds and harming our own health and wellbeing.

The United States of America was at a crossroads. We had a choice to make, would we continue down this road to ruin, or would we value our air, water and wildlife enough to be good stewards and take a different route?

Correspondence to: Jamie Rappaport Clark, e-mail: jclark@defenders.org
Fortunately, we realized that the air, the rivers and streams, and the plants and animals that inhabit our country were too precious, too valuable to let perish; that these wonders were what make the United States special; and that we had a responsibility to future generations to conserve our natural heritage. So we chose the right road, the road to responsible stewardship and recovery.

This was not a patrician debate, where one side won out with a slim majority. Just the opposite was true; conservation of our natural resources used to be a broadly held and proud American value. Across the political spectrum, there was near universal agreement. Indeed, many of our nation's great conservation laws were passed with the enthusiastic support of wide bipartisan majorities. This was especially true of the Endangered Species Act (ESA), which passed in 1973 and was signed into law by Republican President Richard Nixon.

Thanks to these visionary leaders and the communities that spurred them on, we have made great strides over the past forty years. Our air is cleaner, our rivers and streams are healthier, and many wildlife species are recovering. During this time, we have also discovered many more complex and important tangible values of wildlife.

Our native plants and animals are nature's medicine cabinet. Each species has its own unique biochemical defenses, signals, and enzymes that have the potential to treat some of the most devastating human ailments. Drugs developed from the Pacific yew tree and purple foxglove flower have already helped millions of people with cancer and heart disease. Studies have shown that antibodies and proteins in crocodile blood have the potential to kill the virus that causes HIV/AIDS and bacteria resistant to penicillin. The Houston toad secretes serotonin—an essential 
chemical in our brains-and alkaloids used to treat heart and neurological disease. The alkaloids are thought to have analgesic properties quite possibly more powerful than morphine. Researchers believe that the ability of the desert pupfish to survive in hot springs may lead to a treatment for kidney disease. Scientists are working to develop treatments for serious infections by treating them with proteins isolated from the blood of alligators, a species whose populations have completely recovered and removed from the endangered species list. Our plants and wildlife continue to yield new medical discoveries that greatly benefit us all.

Healthy ecosystems provide Americans with essential life sustaining services virtually free of charge. In addition to providing a home for endangered species, our natural habitats help purify our water, control the climate, recycle nutrients, and protect us from extreme flooding. These ecosystem services that we often take for granted, are now widely believed by many economists to have real monetary value. According to a 2011 study prepared for the National Fish and Wildlife Foundation, "The value of ecosystem services provided by natural habitat in the 48 contiguous United States amounts to about $\$ 1.6$ trillion annually, which is equivalent to more than 10 percent of the U.S. GDP."

People travel to certain parts of our country just to see the wildlife there: gray wolves bring $\$ 35$ million to the tourism industry annually to the Yellowstone region; thousands of tourists purchase tickets for whale watching cruises along the Atlantic and Pacific coasts, generating more than $\$ 11$ million in boat ticket sales each year; and manatees swimming around the inlets along Florida's coastline generate about $\$ 10$ million annually from visitors eager to see these loveable sea cows up close.

Our country would look dramatically different if we had not committed to the protections provided by this landmark legislation almost 40 years ago. Bald eagles would not be numerous along our shorelines and mountain ridges; peregrine falcons would likely have vanished; grizzly bears and wolves would be missing from western land- scapes; panthers would be gone from south Florida; bull trout would no longer be swimming in our streams; and black footed ferrets would have vanished from the prairies.

The ESA has delivered on what it was originally intended to do: reverse the slide of listed plants and animals toward extinction and buy time for their recovery. But as we celebrate its 40th anniversary and all of its successes, the future of our most imperiled wildlife is at a crossroads, one that compels us to redouble our efforts and demand that action be taken now to further unlock the ESA's immense conservation potential. Despite all the species of plants and animals the act has saved from extinction, far too many protected species are still in decline due to a plethora of threats including climate change, land conversation, invasive species, lack of funding for recovery efforts, and Congressional attacks on the very law that has been a keystone for wildlife conservation in the United States of America.

To be successful in saving imperiled wildlife, we must help the federal wildlife agencies in charge make the law work more effectively and efficiently for both wildlife and for people. We must demand bold conservation goals for endangered species, speed up recovery efforts and put protected species on the road to recovery before they slip further toward extinction. And we must all do our part to better mobilize the huge public constituency that exists for wildlife conservation. As responsible stewards of our planet, we must be mindful of our obligations to future generations.

We are once again at a crossroads. Which route will we take this time, the road to recovery or extinction?

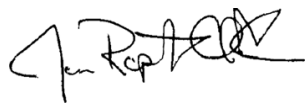

Jamie Rappaport Clark

President and CEO of Defenders of Wildlife Washington, DC, USA

Published online: November 6, 2013 